\title{
IMPLEMENTASI MODEL EBIT - EPS DALAM PENGAMBILAN KEPUTUSAN STRUKTUR MODAL PADA PT LIPPO KARAWACI, Tbk.
}

\author{
Ahmad Safiudin \\ Department of Management FEB UMM \\ E-mail: ahmad.safiudin92@gmail.com
}

\begin{abstract}
This research aims to determine the use of an optimal capital structure to meet the needs of additional funds in PT Lippo Karawaci Tbk in 2016. EBIT EPS analysis was employed to use the model as a tool.

The result indicated that a 100\% PT. Lippo Karawaci Tbk. 's additional fund is based on debt. As an alternative funding, debt is resulted the highest EPS than others. The debt used can lead interest expense increase. The company needs to pay attention to the risks to avoid bankruptcy.
\end{abstract}

Keywords : Capital Structure, Optimal Capital Structure, EBIT-EPS Analysis.

\section{PENDAHULUAN}

Tempat tinggal merupakan kebutuhan dasar manusia setelah sandang pangan dan kesehatan fisik terpenuhi. Kebutuhan akan tempat tinggal pada dasarnya merupakan tujuan utama seseorang dalam melangsungkan kehidupannya untuk mencapai kesejahteraan dan dapat hidup lebih baik. Selain tempat tinggal sebagai tempat berlindung dari gangguan alam dan makhluk hidup lainnya, rumah juga sebagai sarana perwujudan jati diri. Pemahaman tempat tinggal tidak lagi hanya dipandang sebagai tempat untuk berlindung, namun bergeser ke berbagai aspek kehidupan.

Dari kebutuhan dasar manusia akan tempat tinggal maka pengadaan usaha dibidang property dan real estate sangat dibutuhkan untuk menunjang terpenuhinya kebutuhan tersebut. Disamping itu pengadaan usaha dibidang property ini diharapkan dapat berperan sebagai salah satu lokomotif perekonomian dan penciptaan lapangan kerja yang dapat menaikkan taraf hidup kesejahteraan kehidupan pendorong pertumbuhan perekonomian.

Perusahaan property itu sendiri merupakan salah satu sektor industri yang terdaftar di Bursa Efek Indonesia. Di Indonesia industri properti saat ini mengalami perkembangan yang pesat. Hal ini terjadi karena semakin meningkatnya jumlah penduduk sedangkan persediaan lahan yang ada bersifat tetap. Saat ini ada 50 perusahaan sektor property dan real estate yang sahamnya tercatat di Bursa Efek Indonesia, diantaranya yaitu PT Lippo Karawaci, Tbk. Perusahaan ini merupakan yang terbesar dalam industri property, tercatat dari nilai 
aset, dan total keuntungan yang didapat selalu berada di tingkat pertama. Data nilai aset, nilai ekuitas, nilai utang PT Lippo Karawaci, Tbk. dapat dilihat pada Tabel 1

Tabel 1. Nilai aset, ekuitas dan utang PT Lippo Karawaci, Tbk.

\begin{tabular}{llll}
\hline Tahun & $\begin{array}{l}\text { Nilai } \\
\text { Aset } \\
\text { (Miliar } \\
\text { Rupiah) }\end{array}$ & $\begin{array}{l}\text { Nilai Ekuitas } \\
\text { (Miliar Rupiah) }\end{array}$ & $\begin{array}{l}\text { Nilai } \\
\text { Utang }\end{array}$ \\
\hline $\mathbf{2 0 1 0}$ & 16.155 & 8.225 & 7.931 \\
$\mathbf{2 0 1 1}$ & 18.259 & 9.409 & 8.850 \\
$\mathbf{2 0 1 2}$ & 24.869 & 11.470 & 13.399 \\
$\mathbf{2 0 1 3}$ & 31.308 & 14.169 & 17.140 \\
$\mathbf{2 0 1 4}$ & 37.856 & 17.621 & 20.236 \\
$\mathbf{2 0 1 5}$ & 41.327 & 18.917 & 22.410 \\
\hline
\end{tabular}

Berdasarkan Nilai aset, ekuitas dan utang pada Tabel 1.1, dapat ditunjukkan bahwa PT Lippo Karawaci, Tbk. selalu mengalami peningkatan setiap tahunnya. Penggunaan proporsi struktur modal tiap tahunnya mampu meningkatkan nilai EPS. Peningkatan nilai EPS tertinggi terjadi pada tahun 2014 sebesar Rp 112, meningkat sebesar $107 \%$ dari Rp 54 dengan proporsi struktur modal pada tahun 2014 modal sendiri $47 \%$ dan utang $53 \%$. Hal ini menunjukkan bahwa penentuan struktur modal pada tahun 2014 optimal dengan pencapaian nilai EPS yang tinggi.

Perusahaan dalam memperluas serta mengembangkan bisnis guna menjaga kelangsungan hidup perusahaan maka PT Lippo Karawac Tbk perlu untuk melakukan tambahan modal. Perusahaan pengembang properti terbesar di Indonesia tersebut akan memulai pembangunan tahap pertama proyek terbaru yang berlokasi di CBD (Central Business District) Township
Lippo Village Karawaci. Proyek prestesius yang tersebut mengusung nilai proyek berkisar Rp 200 Triliun, PT Lippo Karawaci perlu adanya tambahan dana untuk pelaksanaan proyek

(www.finance.detik.com)

tersebut.

Setiap perusahaan dalam menjaga kelangsungan hidup dari usaha yang didirikan memiliki strategi sendiri dalam penentuan kebijakannya, karena tujuan dari perusahaan secara umum meliputi: kelangsungan hidup, pertumbuhan dan profitabilitas (Warsono,2002:2). Manajemen perusahaan dapat saling bekerjasama dalam menentukan strategi demi terciptanya tujuan dari perusahaan. Strategi tersebut tentunya berkaitan dengan kebijakan dalam penentuan keputusan keuangan jangka pendek maupun jangka panjang perusahaan.

Analisis pada struktur modal pada prinsipnya bertujuan untuk mengukur seberapa besar pengaruh penggunaan utang terhadap harga saham perusahaan, karena perusahaan akan memutuskan apakah perusahaan akan menggunakan utang sebagai sumber pendanaannya atau menggunakan modal sendiri. Perusahaan yang memanfaatkan utang sebagai sumber pendanaannya, maka perusahaan harus mengukur seberapa besar jumlah penggunaan utang tersebut. Pada prinsipnya perusahaan harus memilih struktur modal yang dapat memaksimumkan harga saham perusahaan.

Pemilihan struktur modal yang optimal perlu memperhatikan hubungan antara EBIT dan EPS pada berbagai alternatif pendanaannya. Besarnya EPS sangat tergantung 
pada pemilihan struktur modal perusahaan, karena EPS merupakan laba per lembar saham yang tersedia bagi para pemegang saham yang diperoleh dari laba perusahaan dikurangi biaya bunga dan deviden saham preferen, sedangkan EBIT tidak tergantung pada leverage keuangan. Analisis EBIT-EPS ini dapat digunakan perusahaan dalam melihat dampak dar berbagai alternatif pendanaan yang dipilih terhadap EPS pada tingkat EBIT yang berbeda-beda.

Berdasarkan latar belakang tersebut penulis tertarik untuk meneliti keputusan struktur modal yang tepat menggunakan model EBIT-EPS sebagai alat analisis pada perusahaan sektor properti dalam melakukan penambahan modal pada periode berikutnya untuk memenuhi permintaan penjualan yang semakin meningkat. Berdasarkan penejelasan tersebut penulis ingin melakukan penelitian dengan judul "Implementasi Model EBIT-EPS dalam Pengambilan Keputusan Struktur Modal pada Sektor Properti yang tercatat di BEI".

Berdasarkan latar belakang yang telah dijabarkan diatas, maka dapat diambil rumusan masalah sebagai berikut: "Bagaimana keputusan struktur modal yang seharusnya pada PT Lippo Karawaci, Tbk. tahun 2016?

Berdasarkan

rumusan

masalah yang ada maka tujuan dari penelitian ini adalah untuk menentukan keputusan struktur modal yang optimal di tahun 2016 pada PT Lippo Karawaci, Tbk.

\section{TINJAUAN PUSTAKA}

Menurut Ambarwati (2010:1) Struktur modal sangat penting bagi perusahaan karena menyangkut kebijakan penggunaan sumber dana yang paling menguntungkan. Kebutuhan pendanaan perusahaan dapat menggunakan modal sendiri dan modal asing atau utang. Perusahaan jika menggunakan utang maka akan menanggung biaya tetap yaitu bunga. Masalah leverage muncul karena perusahaan menggunakan asset yang menyebabkan harus membayar biaya tetap dan menggunakan utang yang menyebabkan perusahaan menanggung beban tetap.

Sartono

(2010:225)

menyatakan bahwa struktur modal merupakan perimbangan jumlah utang jangka pendek yang bersifat permanen, utang jangka panjang, saham preferen dan saham biasa. Modal dalam suatu bisnis merupakan salah satu sumber pembiayaan agar perusahaan dapat menjalankan aktivitasnya. Setiap perusahaan dalam melaksanakan kegiatannya selalu berupaya untuk menjaga keseimbangan finansialnya. Struktur modal (capital structure) adalah perbandingan atau imbangan pendanaan jangka panjang perusahaan yang ditunjukkan oleh perbandingan utang jangka panjang terhadap modal sendiri. (Martono dan Harjito, 2001 : 239).

Warsono (2002 : 233) menyatakan bahwa pembahasan struktur modal (capital structure) berkaitan dengan penentuan bauran (mix) pembelanjaan jangka panjang 
perusahaan. Struktur modal mempunyai pengertian yang berbeda dengan struktur keuangan (financial structure). Struktur modal hanya merupakan bagian dari struktur keuangan. Struktur keuangan merupakan kombinasi atau bauran dari segenap pos yang termasuk dalam sisi kanan neraca keuangan perusahaan (sisi pasiva), sedangkan struktur modal merupakan bauran dari segenap sumber pembelanjaan jangka panjang yang digunakan perusahaan.

Menurut Warsono (2003:256)

Pengambilan keputusan struktur modal diperlukan alat-alat analisis yang digunakan untuk menganalisis bagaimana pengaruh pengubahan bauran komposisi sumber modal dapat mempengaruhi penilaian dan biaya modal. Secara umum ada tiga macam metode pengambilan keputusan struktur modal

\section{Keputusan}

untuk menggunakan utang atau saham biasa dalam kapitalisasi perusahaan menghasilkan dua jenis pengaruh solvabilitas keuangan. Risiko yang bertambah pada pendapatan per lembar saham (EPS) karena penggunaan kewajiban keuangan tetap dan berhubungan dengan tingkat EPS pada suatu EBIT tertentu di bawah suatu struktur modal spesifik. Analisis EBIT-EPS digunakan untuk mengukur pengaruh perubahan EBIT terhadap EPS yang digunakan untuk mengukur pengembalian para pemilik sahamnya. (warsono, 2003:257)

Menurut warsono (2003:260)

Dampak keputusan pembelanjaan terhadap biaya modal saham biasa perusahaan sama sekali tidak diperhatikan, padahal investor selalu memperhatikan besar-kecilnya dan kadar risiko arus pendapatan perusahaan. Analisis EBIT-EPS hanya memperhatikan berapa atau

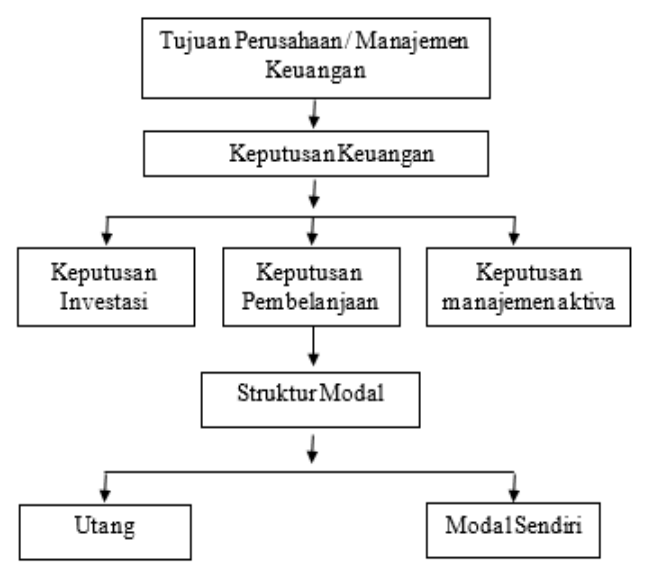

besar-kecilnya arus pendapatan tersebut tanpa memperlihatkan risiko atau besar-kecilnya kemungkinan pendapatan itu gagal. Kerangka pikir ini menjelaskan bahwa tujuan perusahaan berdiri sebenarnya adalah memaksimalkan kekayaan dari pemilik perusahaan, tetapi untuk memaksimalkan kekayaan perusahaan harus dapat mengambil keputusan-keputusan yang nantinya bisa membuat perusahaan itu makmur, yaitu dengan cara keputusan struktu modal. Adapaun kerangka pemikiran dapat dilihat pada Gambar di atas.

\section{METODE PENELITIAN}

Jenis peneliti ini merupakan jenis penelitian sensus, dalam arti penelitian yang menelaah kepada satu kasus yang dilakukan secara intensif selanjutnya dianalisis dan memberkan solusi kepada perusahaan.

Variabel pertama yang digunakan dalam penelitian ini adalah bunga, pendapatan sebelum pajak, pajak, 
pendapatan setelah pajak, saham yang beredar, pendapatan lembar saham, EBIT, Trend linier untuk mengestimasi nlai EBIT dan besarnya modal tahun berikutnya, peramalan besarnya tambahan modal tahun 2016.

Jenis Data yang digunakan pada penelitian ini terdiri dari data kuantitatif berupa laporan keuangan perusahaan dengan periode waktu 2010 sampai 2015. Sumber data yang digunakan adalah data sekunder yang diunduh melalu www.idx.co.id. Teknik pengumpulan data yang digunakan adalah teknis dokumentasi berupa laporan keuangan tahunan dan neraca pada PT. Lippo Karawaci, Tbk.

Teknik analisis data yang digunakan dalam penelitian ini yaitu menggunakan alat analisis EBIT EPS. Teknik analisis ini melalui beberapa tahap. Tahap pertama, melakukan peramalan tingkat EBIT, peramalan besarnya modal, peramalan besarnya tambahan modal tahun 2016, Kemudian melakukan analisis EBIT-EPS.

\section{HASIL PENELITAN DAN PEMBAHASAN}

Berdasarkan analisis data yang digunakan hasil proyeksi besarnya EBIT pada tahun 2016 dengan menggunakan metode trend linier yang menghasilkan nilai proyeksi EBIT PT. Lippo Karawaci, Tbk. pada tahun 2016 sebesar Rp. 2.774.603.890.176.

Berdasarkan besarnya modal PT. Lippo Karawaci Tbk dari tahun 2010-2015 yang dapat dilihat pada Tabel 4.3., maka dapat di proyeksikan besarnya modal pada tahun 2016 dengan menggunakan metode trend linier yang menghasilkan nilai proyeksi jumlah modal pada tahun 2016 sebesar Rp. 45.602.570.727.094

$$
\text { Besarnya tambahan modal }
$$

yang dibutuhkan PT. Lippo

Karawaci Tbk. pada tahun 2016 berdasarkan proyeksi besarnya jumlah modal pada tahun 2016 adalah Rp. 4.276.012.549.045.

Analisis

EBIT-EPS

merupakan salah satu alat analisis dalam pengambilan keputusan struktur modal jika perusahaan menginginkan tambahan dana untuk membiayai kegiatan operasionalnya. Berdasarkan data yang diperoleh dapat dihasilkan tabulasi pengaruh penambahan sumber pembelanjaan alternatif terhadap EPS.

Hasil dari pengaruh sumber pembelanjaan alternatif PT. Lippo Karawaci Tbk adalah sebagai berikut:

\begin{tabular}{llr}
\multicolumn{2}{c}{ Pengunaan } & alternatif \\
pendanaan & $100 \%$ & menggunakan \\
hutang & memperoleh & hasil \\
perhitungan & diperoleh bahwa PT.
\end{tabular}
Lippo Karawaci Tbk untuk tahun 2016 dengan menggunakan sumber pembelanjaan utang $100 \%$ dalam mendapatkan dana tambahan dengan proyeksi nilai EBIT sebesar Rp. 2.774.603.890.176,00. Penggunaan proporsi utang $100 \%$ menyebabkan peningkatan beban bunga menjadi sebesar Rp. 454.948.125.040,00 dengan tingkat suku bunga sebesar $6,5 \%$ sesuai dengan BI rate pada tahun 2016 dan tingkat pajak sebesar $13,8 \%$ dan jumlah saham yang beredar tetap dari kondisi awal sebelum adanya penambahan modal sebesar 23.077.689.619 lembar saham yang akan menghasilkan 
pendapatan per lembar saham (EPS) untuk utang 100\% sebesar Rp. 87

Dari hasil perhitungan pengaruh perubahan EBIT-EPS pada alternatif sumber pendanaan dengan penggunaan utang $100 \%$ dan saham 0\% dapat diketahui nilai titik indifferent EBIT $^{*}$ sebesar Rp. 1.048.226.801.218.

Keputusan pendanaan harus mempertimbangkan secara teliti sifat dan biaya dari sumber dana yang dipilih. Hal ini karena masingmasing sumber pendanaan mempunyai konsekuensi financial yang berbeda-beda. Proporsi penggunaan sumber dana intern dan ekstern dalam memenuhi kebutuhan dana perusahaan yang selanjutnya disebut dengan struktur modal menjadi sangat penting dalam manajemen keuangan perusahaan. Penggunaan alternatif sumber dana perusahaan harus didasarkan pada cost dan benefit-nya antara biaya modal dan keuntungan penggunaan utang yaitu biaya kebangkrutan dan biaya pajak.

Hasil

perhitungan

menunjukkan penentuan struktur modal tahun 2016 pada PT. Lippo Karawaci Tbk, perusahaan sebaiknya menggunakan komposisi utang obligasi $100 \%$ sebagai sumber pembiayaan dalam pemenuhan kebutuhan dananya karena komposisi penggunaan utang $100 \%$ berupa obligasi tersebut menghasilkan pendapatan perlembar saham (EPS) Rp. 87. Nilai EPS tersebut merupakan nilai paling tinggi yang didapatkan diantara alternatif skenario penggunaan sumber pembelanjaan yang lain. Penggunaan utang yang tinggi biaya modal yang dikeluarkan yaitu jumlah beban bunga yang tinggi. Setelah perusahaan mendapatkan laba yang cukup tinggi, perusahaan dapat menggunakan labanya untuk mengurangi hutang sehingga penggunaan hutang dalam pendanaannya menjadi turun.

Risiko yang intern didalam operasi sebuah perusahaan jika perusahaan tidak memiliki utang maka beban pajak yang ditanggung akan semakin tinggi karena bunga merupakan pos deduksi perhitungan pajak. Perusahaan yang mempunyai utang (dan harus membayar bunga) akan membayar pajak (income tax) dalam jumlah yang lebih kecil. Penggunaan utang yang berlebihan akan menimbulkan risiko keuangan, karena semakin banyak utang maka semakin tinggi beban yang ditanggung. Beban yang harus ditanggung saat menggunakan utang adalah biaya kebangkrutan, biaya keagenan, biaya bunga dan sebagainya, ini yang dinamakan dengan teori trade off.

\section{SIMPULAN}

Dari hasil analisis dan pembahasan pada bab sebelumnya dapat ditarik kesimpulan bahwa penentuan keputusan struktur modal tahun 2016 pada PT. Lippo Karawaci yang seharusnya dilakukan yaitu menggunakan $100 \%$ utang. Penggunaan alternatif dana tambahan $100 \%$ menggunakan utang tersebut dapat menghasilkan nilai EPS yang lebih besar dibandingkan dengan komposisi alternatif pendanaan yang lain. Penggunaan utang yang lebih besar maka akan menyebabkan meningkatnya beban bunga yang harus ditanggung oleh perusahaan sehingga dapat meningkatkan risiko 
terjadinya kebangkrutan. Penggunaan utang yang lebih besar juga mampu untuk meningkatkan keuntungan karena beban bunga yang dihasilkan dapat digunakan sebagai pengurang.

Irawanti, Aris Eka. 2014. Keputusan Struktur Modal Pada Perusahaan Sektor Semen Yang Tercatat Di Bursa Efek Indonesia. Skripsi, Fakultas Ekonomi dan Bisnis Universitas Muhammadiyah Malang.

Martono dan Agus Harjito. 2001. Manajemen Keuangan. Edisi Keempat. Yogyakarta. Margaretha, Farah. 2011. Manajemen Keuangan. Erlangga. Jakarta

Ridwan dan Barlian, Inge. 2003. Manajemen Keuangan. PT Intan Sejati. Klaten.

Riyanto, Bambang. 2002. DasarDasar Pembelanjaan Perusahaan. BPFE. Yogyakarta

Sartono, Agus. 2010. Manajemen Keuangan. BPFE. Jogjakarta.

Sugiyono. 2009. Metode Penelitian Kuantitatif dan Kualitatif. CV.Alfabeta: Bandung

\section{DAFTAR PUSTAKA}

Ambarwati, Ari DS. 2010. Manajemen Keuangan. Graha Ilmu. Yogyakarta.

Husnan, Suad. 2001. Manajemen Keuangan. BPFE. Jogjakarta.

Sulaiman, Yolan. 2008. Analisis Keputusan Struktur Modal Pada Perusahaan Sektor Rokok. Skripsi, Fakultas Ekonomi dan Bisnis Universitas Muhammadiyah Malang.

Warsono, 2003, Manajemen Keuangan Perusahaan. Edisi Ketiga, cetakan pertama, UMM Press, Malang

Weston, J Fred dan Eugene F Brigham. 1990. DasarDasar Manajemen Keuangan. Jilid 1. Edisi Kesembilan. Alih bahasa Alfonsus Sirait. Erlangga. Jakarta.

www.idx.co.id. Diunduh tanggal 13 januari 2016

http://finance.detik.com/read/2014/0 5/22/163909/2589819/1016/lippobangun-kota-mewah-rp-200-triliundi-tangerang. Diakses tanggal 13 januari 2016 